\title{
Antioxidant activity and prevention of pork meat lipid oxidation using traditional Mexican condiments (pasilla dry pepper, achiote, and mole sauce) Emilio ALVAREZ-PARRILLA ${ }^{1 *}$, Gilberto MERCADO-MERCADO ${ }^{1}$, Laura Alejandra DE LA ROSA ${ }^{1}$, José Alberto LÓPEZ DÍAZ ${ }^{2}$, Abraham WALL-MEDRANO ${ }^{2}$, Gustavo Adolfo GONZÁLEZ-AGUILAR ${ }^{3}$
}

\begin{abstract}
Considering the extensive use of hot peppers and spicy sauces in the Mexican cuisine, in the present paper, three widely consumed Mexican condiments (mole sauce, achiote, and pasilla hot pepper) were analyzed for their total phenols, flavonoids and proanthocyanidins, antioxidant activity, and protective effect against lipid oxidation in chopped pork meat. All samples were extracted first with methanol and then with acetone, and the extracts were compared. Pasilla pepper showed the highest phenolic and flavonoid content in both solvents, followed by mole and achiote. Achiote showed the highest proanthocyanidin concentration. All samples showed high antioxidant activity, and good correlations with phenolic compounds and flavonoids, while no correlation was observed in the case of condensed tannins. Mole sauce methanolic extract showed the highest inhibition of pork meat oxidation, followed by pasilla pepper, and finally achiote paste extracts. These results suggest that these condiments are useful to prevent meat lipid oxidation during storage.
\end{abstract}

Keywords: hot pepper; Bixa orellana L.; phenolic compounds; flavonoids; proanthocyanidins; TBARS.

\section{Introduction}

In 2010, the Traditional Mexican cuisine, based on corn, beans, and hot peppers was named an "intangible cultural heritage" by UNESCO (United Nations Organization for Education, Science and Culture, 2010). Mole and achiote pastes are two of the most popular condiments in the Traditional Mexican cuisine. There are different kinds of mole sauces which are classified according to their color and geographical origin; all of them compromise a complex mixture of 4 to 7 different fresh and dry hot peppers ground with nuts, chocolate, oil, dry corn tortilla, and several spices in different proportions (Barros, 2005). Achiote paste is a condiment similar to "coloral" prepared by a mixture of corn flour with annatto (Bixa orellana L.) seeds extract, rich in both hydrophilic and lipophilic phytochemicals (Tocchini \& Mercadante, 2001). Both pastes are commonly used to prepare different kinds of marinated meats, including turkey, chicken, pork, and fish among others. Pasilla dry pepper is a mild to medium-hot, dark colored sun dried hot pepper obtained from chilaca pepper (Capsicum annuum) with a characteristic and highly appreciated flavor; it is used in the formulation of mole pastes.

Although it has been stated that spices and condiments may prevent several chronic and acute diseases, mainly due to their phytochemical composition (phenolic compounds, carotenoids, and tocopherols), there is a lack of information on the beneficial effects of Mexican spices \& condiments (MercadoMercado et al., 2013). It is also known that phytochemicals present in spices and condiments used to marinate meat products may prevent lipid oxidation during cooking and storage (Castro et al., 2011; Kong et al., 2010; Marangoni \&
Moura, 2011; Martínez et al., 2006; Mercadante et al., 2010; Olorunsanya et al., 2009; Sancho et al., 2011). Lipid oxidation is a deteriorative process in which unsaturated fatty acids react with oxygen or other free radicals by a typical chain reaction mechanism, giving rise to the formation of lipid hydroperoxides and other secondary products such as aldehydes, responsible for the development of rancidity and food deterioration (Shahidi \& Zhong, 2010). Among meat products, pork is highly prone to lipid oxidation due to its large amount of unsaturated fatty acids, which are more susceptible to oxidation (Juntachote et al., 2006). Phytochemicals and specifically phenolic compounds prevent lipid oxidation by several mechanisms which include free radical scavengers, reducing agents, metal chelators, and single oxygen quenchers among others (Shahidi \& Zhong, 2010). Considering that there is a lack of information on both the composition and the protective effects of Mexican condiments, despite their use in meat products; the aim of the present study was to evaluate the proximal composition, total phenols, flavonoids and tannins, antioxidant activity, and the ability to inhibit pork meat oxidation of methanol and acetone extracts obtained from Mexican spicy condiments.

\section{Materials and methods}

\subsection{Materials}

Two black mole pastes, one artisanal sample (GM) from Tlapa, Guerrero (Mexico) and a commercial brand (Doña María $\left.^{\circledR}, \mathrm{MM}\right)$; two commercial achiote pastes (LOL TUN ${ }^{\circledR}$,

Received 28 Feb., 2014

Accepted 25 Mar., 2014 (006308)

Departamento en Ciencias Químico Biológicas, Instituto de Ciencias Biomédicas Chihuahua, Universidad Autónoma de Ciudad Juárez - UACJ, México, e-mail:ealvarez@uacj.mx

${ }^{2}$ Departamento en Ciencias de la Salud, Instituto de Ciencias Biomédicas Chihuahua, Universidad Autónoma de Ciudad Juárez - UACJ, México

${ }^{3}$ Centro de Investigación en Alimentación y Desarrollo, Hermosillo, Sonora, México

${ }^{*}$ Corresponding author 
LT, and Rogelio Bueno $\left.{ }^{\circledR}, \mathrm{RB}\right)$; and one sample of dry Pasilla hot pepper (PP) were used in the present research. MM. LT, $\mathrm{RB}$, and PP were purchased from a local supermarket in the Ciudad Juarez, Chihuahua, Mexico. GM was purchased from local supermarkets in Tlapa, Guerrero, Mexico. All samples were frozen at $-80^{\circ} \mathrm{C}$ for $24 \mathrm{~h}$, freeze dried for $48 \mathrm{~h}$ (Labconco 6 freezone, Labconco Corporation, Kansas City, MO, USA), milled using a laboratory miller, and stored at $-80^{\circ} \mathrm{C}$. Moisture was determined from the difference in weight before and after lyophilization. Placenta and seeds were removed from PP because this pepper is eaten without seeds.

\subsection{Proximate analysis}

Moisture content was determined by lyophilization (48 h) in order to prevent polyphenol and antioxidant activity losses. Protein, ash, and fat were determined according to the AOAC (Association of Official Analytical Chemistry, 2000) procedures, while total carbohydrates were calculated by difference. For protein determination, a conversion factor of 6.25 was used, in accordance with previously reported protein values for hot peppers (Vega-Gálvez et al., 2009).

\subsection{Extraction of phenolic compounds}

Phenolic compounds were extracted according to AlvarezParrilla et al. (2011) using 80\% methanol (1:10 sample methanol ratio) as solvent (methanol extracts, $\mathrm{ME}$ ). Sample residues were re-extracted with $80 \%$ acetone (1:10 sample acetone ratio), following the protocol for methanol extracts (Acetone extracts, $\mathrm{AE}$ ). Yield of both $\mathrm{ME}$ and $\mathrm{AE}$ extracts of each sample were determined for further analysis.

\subsection{Total phenolic content}

Total phenols in ME and AE were determined using the Folin-Ciocalteu's reagent according to Alvarez-Parrilla et al. (2011) with a slight modification in order to scale it to a microplate reader (XMark microplate reader, Bio-Rad Mexico, Mexico City). Gallic acid was used as a standard, and the results were expressed as mg gallic acid equivalent (GAE)/100 $\mathrm{g}$ of fresh weight.

\subsection{Total flavonoid content}

Total flavonoids were determined according to a modification of the methodology reported by Alvarez-Parrilla et al. (2011) in order to scale them to a microplate reader. Catechin was used as a standard, and the results were expressed as mg catechin equivalents (CE)/100 $\mathrm{g}$ of fresh weight.

\subsection{Proanthocyanidins (Condensed Tannins) contents}

Proanthocyanidins were determined by the vanillin assay, according to the method of de la Rosa et al. (2011) scaled to a microplate reader. Catechin was used as a standard, and the results were expressed as milligram catechin equivalents (CE) per $100 \mathrm{~g}$ of fresh weight.

\subsection{Antioxidant activity}

Determination of DPPH radical scavenging activity. The DPPH radical scavenging activity assay was performed by the method of Brand-Williams et al.; (1995) modified to scale it to a microplate reader. Trolox (25 to $400 \mu \mathrm{M}$ in methanol) was used as a standard, and the results were reported as $\mu \mathrm{mol}$ of TE/ $100 \mathrm{~g}$ of sample fresh weight.

Determination of ABTS*- scavenging activity. The ABTS* scavenging activity assay was performed according to Madhujith \& Shahidi (2007) with slight modifications to scale it to a microplate reader (absorbance read at $734 \mathrm{~nm}$ ). Trolox (25 to $400 \mu \mathrm{M}$ ) was used as a standard, and the results were expressed as $\mu \mathrm{mol}$ of TE/ $100 \mathrm{~g}$ of sample fresh weight.

Ferric Reducing/Antioxidant Power (FRAP) assay. FRAP assay was determined as previously reported (AlvarezParrilla et al., 2007) using a XMark ${ }^{\mathrm{TM}}$ microplate reader. Trolox $(16.25$ to $130 \mu \mathrm{M})$ was used as a standard, and the results were expressed as $\mu \mathrm{mol}$ of TE/100 $\mathrm{g}$ of sample fresh weight.

\subsection{Oxidative stability using the cooked comminuted pork method}

The effect of extracts on the oxidative stability of cooked and stored $\left(4^{\circ} \mathrm{C}\right)$ pork meat was carried out according to AlvarezParrilla et al. (2012). The phenolic content per gram of extract of all samples was used in order to determine the exact amount of each extract necessary to prepare $100 \mathrm{ppm}$ (mg GAE/kg chopped pork meat) sample mixtures to evaluate the protective effect of these extracts against lipid oxidation. Thiobarbituric acid reactive substances (TBARS) from fresh uncooked chopped pork meat and cooked meat were monitored every 4 days for 16 days. TBARS results were expressed as mg MDA equivalents/ $\mathrm{kg}$ sample (fresh uncooked chopped pork meat). Inhibition of TBARS formation was determined from the difference between control and treated samples, according to Equation 1:

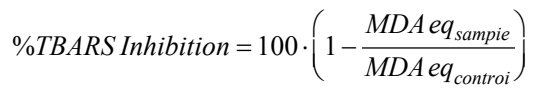

\subsection{Statistical analysis}

All analyses were carried out in quadruplicate. Values are expressed as mean $\pm \mathrm{SD}$. One way ANOVA, ANCOVA (covariates: moisture and fat), and Tukey-Kramer analyses were performed in order to determine statistical differences $(\mathrm{p}<0.05)$ between the samples. The relationship between the antioxidant activity (ABTS, DPPH, FRAP) with proximal and phenolic compounds (total phenols, flavonoids and proanthocyanidins) was assessed with Pearson productmoment correlation $(r)$ and stepwise multiple linear regression (SWMRM), using the bi-directional elimination method and the Efroymson algorithm (Efroymson, 1960). All data were analyzed using the commercial software SPSS 21 (SPSS Inc. Headquarters, Chicago, IL, USA). 


\section{Results and discussion}

\subsection{Proximal analysis}

In the present study, two of the most consumed condiments in traditional Mexican cuisine: Mole, and achiote, and pasilla pepper, a sun dry hot pepper commonly used in the elaboration of hot sauces, including Mole, were studied. Table 1 depicts the proximal composition of two mole pastes (GM, MM), two achiote pastes (LT, RB), and one pasilla pepper (PP) samples. While both achiotes had similar composition, moles differed from each other in moisture, lipid, and carbohydrate contents. In general terms, mole pastes showed the highest moisture (78\%) and fat (11\%) content; achiotes showed the highest ash (12\%, probably as salt), PP carbohydrate (61\%), and protein (12\%) contents. Proximal composition of PP was similar to that reported for pasilla (Cortez García, 2011) and other dry peppers (Hervert-Hernández et al., 2010; Otunola et al., 2010). The high carbohydrate content in PP is probably due to the high fiber and pectin content found in dry peppers (Cortez García, 2011).

\subsection{Total phenols, flavonoids, and proanthocyanidins content}

Condiments and spices are known to be good sources of antioxidant phytochemicals such as phenolic compounds, flavonoids, and tannins; all of them are associated with a beneficial effects against degenerative and cardiovascular diseases (Mercado-Mercado et al., 2013), as well as a protective effect against lipid oxidation in cooked and raw meat (Castro et al., 2011; Kong et al., 2010; Marangoni \& Moura, 2011; Martínez et al., 2006; Mercadante et al., 2010; Olorunsanya et al., 2009; Sancho et al., 2011). Total phenols, flavonoids, and proanthocyanidins (condensed tannins) are summarized in Table 2 .

Results are expressed in terms of fresh weight; however, for comparison purposes, the values were also calculated in terms of dry weight (data not shown). Despite the fact that both mole and achiote are complex matrixes, almost all (>90\%) phytochemicals were extracted with $80 \%$ methanol; a subsequent extraction with $80 \%$ acetone allowed the extraction of remaining phenolic compounds and tannins, which accounted for approximately $10 \%$ of the total solvent-extractable phenolic compounds. Oboh et al. (2011) observed similar results when extracting phenolic compounds from annatto seeds using both polar and non-polar solvents. These results may indicate that all analyzed samples have mainly polar non-polymeric phenolic compounds. An exception to this behavior was the PP sample, in which $30 \%$ of condensed tannins were extracted with acetone. This could indicate that PP contains condensed tannins with a higher degree of polymerization, which are better extracted with acetone (Rosa et al., 2011).

Total phenolic (sum of both methanol and acetone extracts) content ranged from 11.4 (GM) to $1031 \mathrm{mg}$ GAE/100 g FW (PP). Interestingly, mole and achiote extracts showed 96 and $94 \%$ less total phenols [standard error $(\mathrm{EE})=11.2, \mathrm{p} \leq 0.001$ ] than PP, even after considering moisture and fat contents as covariates [standard error $(\mathrm{EE})=3.5, \mathrm{p} \leq 0.001$ ]. Both mole and achiote are complex mixtures made of different ingredients such as corn flour, oil, and water, which, in turn, could create molecular interactions between phenolic compounds and macronutrients (mainly carbohydrates and fat) reducing their extraction capacity. Alternatively, some phenolic compounds may be lost during processing.

PP phenolic content was higher than that reported for fresh hot peppers (Alvarez-Parrilla et al., 2011; Ornelas-Paz et al., 2010), but similar to those reported for chilaca and pasilla dry peppers (Cortez García, 2011; Ornelas-Paz et al., 2010), dry chipotle pepper (Hervert-Hernández et al., 2010), and Italian dry peppers (Loizzo et al., 2013). This high phenolic content is characteristic of all dry fruits and vegetables due to the water loss that concentrates all phytochemicals present in the fresh product (Alasalvar \& Shahidi, 2013).

Table 1. Proximal composition (\%) of Mexican condiments ${ }^{\alpha}$.

\begin{tabular}{ccrrrr}
\hline Sample $^{*}$ & Moisture & Fat & Protein & Ash & Carbohydrates \\
\hline MM & $81.8 \pm 0.4^{\mathrm{a}}$ & $8.8 \pm 3.1^{\mathrm{b}}$ & $2.2 \pm 0.2^{\mathrm{b}}$ & $5.1 \pm 0.4^{\mathrm{c}}$ & $2.1 \pm 0.1^{\mathrm{c}}$ \\
GM & $72.6 \pm 0.3^{\mathrm{b}}$ & $13.9 \pm 0.5^{\mathrm{a}}$ & $2.5 \pm 0.01^{\mathrm{b}}$ & $5.2 \pm 0.5^{\mathrm{c}}$ & $5.8 \pm 0.3^{\mathrm{c}}$ \\
LT & $60.6 \pm 0.3^{\mathrm{c}}$ & $2.8 \pm 0.6^{\mathrm{c}}$ & $3.1 \pm 0.4^{\mathrm{b}}$ & $10.9 \pm 0.1^{\mathrm{b}}$ & $22.6 \pm 0.3^{\mathrm{b}}$ \\
RB & $60.7 \pm 0.3^{\mathrm{c}}$ & $2.1 \pm 0.8^{\mathrm{c}}$ & $2.8 \pm 0.3^{\mathrm{b}}$ & $13.1 \pm 0.1^{\mathrm{a}}$ & $21.3 \pm 0.2^{\mathrm{b}}$ \\
PP & $15.1 \pm 0.3^{\mathrm{d}}$ & $6.0 \pm 3.7^{\mathrm{b}}$ & $12.1 \pm 0.2^{\mathrm{a}}$ & $5.4 \pm 0.1^{\mathrm{c}}$ & $61.4 \pm 0.5^{\mathrm{a}}$ \\
\hline
\end{tabular}

${ }^{\star}$ Mean \pm SD $(\mathrm{n}=4)$. Different superscript letters within a same column means statistical differences $(\mathrm{p}<0.05)$. ${ }^{\star}$ Moles $(\mathrm{GM}, \mathrm{MM})$, achiotes $(\mathrm{LT}, \mathrm{RB})$, and Pasilla pepper $(\mathrm{PP})$ samples.

Table 2. Phenolic content of Mexican condiments\&.

\begin{tabular}{|c|c|c|c|c|c|c|c|c|c|c|}
\hline \multirow[t]{2}{*}{ Sample } & \multirow[t]{2}{*}{$\mathrm{DM}$} & \multicolumn{3}{|c|}{$\begin{array}{c}\text { Total Phenols } \\
\text { mg GAE/100 g FW }\end{array}$} & \multicolumn{3}{|c|}{$\begin{array}{c}\text { Flavonoids } \\
\mathrm{mg} \mathrm{CE} / 100 \mathrm{~g} \mathrm{FW}\end{array}$} & \multicolumn{3}{|c|}{$\begin{array}{l}\text { Proanthocyanidins } \\
\text { mg CE/100 g FW }\end{array}$} \\
\hline & & $\mathrm{ME}$ & $\mathrm{AE}$ & Total & $\mathrm{ME}$ & $\mathrm{AE}$ & Total & $\mathrm{ME}$ & $\mathrm{AE}$ & Total \\
\hline MM & 18.2 & $78.0 \pm 6.5^{b}$ & $0.75 \pm 0.01^{\mathrm{cd}}$ & 78.8 & $40.6 \pm 0.68^{d}$ & $0.34 \pm 0.08^{\mathrm{d}}$ & 40.9 & $45.4 \pm 1.49^{\mathrm{e}}$ & $3.4 \pm 0.07^{c}$ & 48.8 \\
\hline LT & 39.4 & $53.1 \pm 0.06^{c}$ & $3.2 \pm 0.73^{b}$ & 56.3 & $100.0 \pm 0.36^{c}$ & $25.2 \pm 1.2^{\mathrm{a}}$ & 125.2 & $190.9 \pm 3.4^{c}$ & $5.8 \pm 0.77^{\mathrm{b}}$ & 196.7 \\
\hline RB & 39.3 & $56.9 \pm 2.2^{c}$ & $1.8 \pm 0.09^{c}$ & 58.7 & $108.3 \pm 0.83^{b}$ & $3.4 \pm 0.28^{c}$ & 111.7 & $336.0 \pm 1.5^{\mathrm{a}}$ & $5.8 \pm 0.29^{b}$ & 341.8 \\
\hline
\end{tabular}

${ }^{*}$ Mean \pm SD $(\mathrm{n}=4)$. Different superscript letters within a same column means statistical differences $(\mathrm{p}<0.05)$, considering moisture and fat content as covariates. ${ }^{\star} M o l e s(\mathrm{GM}, \mathrm{MM})$, achiotes (LT, RB), and Pasilla pepper (PP) samples; Dry matter (DM, \%), 80\% aqueous methanol extract (ME), $80 \%$ aqueous acetone extract (AE), mean ME+AE (Total). 
Both achiote samples (LT and RB) presented lower phenolic content than that of annatto seed extracts (Castro et al., 2011; Cardarelli et al., 2008). This could be explained considering that achiote paste is a mixture of annatto seeds, corn flour, and other spices such as garlic, vinegar, and salt. Finally, there was a large variability in phenolic content between both mole pastes; as result of the different preparation recipes and origin (MM is a commercial brand while GM is an artisanal product). This variability was observed for all the other parameters, except for FRAP and TBARS, even after considering moisture and fat contents as covariates. To our knowledge, there is no single report on the phytochemical content and antioxidant activity of mole pastes.

Total flavonoids, determined by the aluminum complexation method, ranged from 28.5 (GM) to 551 (PP) $\mathrm{mg} \mathrm{CE} / 100 \mathrm{~g} \mathrm{FW}$. Once again, mole and achiote samples showed 94 and $79 \%$ less total flavonoids than that of PP [standard error $(\mathrm{EE})=2.8$, $\mathrm{p} \leq 0.001]$, even after considering the moisture and fat as covariates [standard error $(\mathrm{EE})=2.1, \mathrm{p} \leq 0.001$ ]. Achiote pastes showed higher flavonoid than total phenol content. These results could be explained due to an overestimation of flavonoids by the Aluminum (III)-chelation method. Al (III) reacts with flavonoids giving rise to a colored complex which is measured at $510 \mathrm{~nm}$ in order to estimate flavonoid concentration. However, catechin has a low molar absorptivity value (about 2-3 times lower than that of the other flavones or flavonols), and consequently if the sample has other flavonoids instead of catechin, an overestimation may occur (Bener et al., 2010). In PP samples the flavonoid content was one half the total phenol content, and its value was similar to that reported for Italian dried peppers (Loizzo et al., 2013). Flavonoid and total phenol content in MM were 5 and 4 times higher than GM, which is probably explained by the differences in their proximal composition (Table 1).

Proanthocyanidins were quantified by the vanillin assay, which is fairly specific for monomeric and polymeric condensed tannins (flavan-3-ols) (Rosa et al., 2011). Proanthocyanidins ranged from 49 (MM) to 342 (RB) $\mathrm{mg} \mathrm{CE} / 100 \mathrm{~g} \mathrm{FW}$ (Table 2). Achiote and PP showed similar proanthocyanidin values, approximately 3 to 8 times higher than mole. Achiote condensed tannins were higher than their total phenol and flavonoid concentration. This may be explained by considering that achiote is a condiment obtained from annatto (Bixa orellana L.) seeds, and that colored seeds (such as annatto seed) are rich in proanthocyanidins (Díaz et al., 2010). Based on the proanthocyanidin values reported in Table 2, it can be inferred that achiote and mole pastes contain low polymerized condensed tannins (soluble in methanol), while PP has high polymerized condensed tannins, which are more soluble in acetone (Rosa et al., 2011).

\subsection{Antioxidant activity}

Two radical scavenging assays (DPPH and ABTS) and one reducing ability assay (FRAP) were used to evaluate the antioxidant activity of all condiments. In order to better compare results, all antioxidant activity values were expressed in terms of $\mu \mathrm{mol} \mathrm{TE} / 100 \mathrm{~g}$ FW, and the results are shown in Table 3. Like total phenols, antioxidant activity was higher in ME than in AE. Similar results were observed by Márquez et al. (2006), when analyzing the FRAP antioxidant activity of Chilean spices and vegetables. Nevertheless, for a better comparison between the samples, antioxidant activity was obtained from the sum of $\mathrm{ME}$ and $\mathrm{AE}$ values and expressed as $\mu \mathrm{mol} \mathrm{TE} / 100 \mathrm{~g} \mathrm{FW}$.

FRAP measures the capacity of an antioxidant to reduce a TPTZ- $\mathrm{Fe}^{3+}$ complex to TPTZ- $\mathrm{Fe}^{2+}$. FRAP values ranged from 27 (GM) to 734 (LT) $\mu \mathrm{mol}$ TE/100 g FW. Both mole samples showed the lowest FRAP values, while the achiote samples showed high variability among themselves (RB was 3 times higher than LT) although both FRAP values were lower compared to those of annatto (Bixa orellana L.) seed methanol extracts (Gutiérrez et al., 2010). This can be explained by the presence of vixin and other carotenoids typically found in annatto seed extracts (Cardarelli et al., 2008), which were only partially extracted in the present study. PP FRAP values were lower compared to those reported for Morita and Guajillo, two typical Mexican dry peppers (Hervert-Hernández et al., 2010), but similar to those reported for dehydrated Spanish hot peppers (Rufián-Henares et al., 2013).

DPPH and ABTS methods measure the scavenging ability of fruit and vegetable extracts against DPPH and ABTS radicals, respectively. DPPH values varied from $2.4(\mathrm{GM})$ to $127(\mathrm{PP})$ $\mu \mathrm{mol} \mathrm{TE} / 100 \mathrm{~g}$ FW, while ABTS ranged from 42 to $2840 \mu \mathrm{mol}$ $\mathrm{TE} / 100 \mathrm{~g}$ FW for the same samples (Table 3). DPPH values of PP were slightly lower than those reported for dehydrated Spanish hot peppers (Rufián-Henares et al., 2013), while ABTS values were similar to those reported for Mexican dry hot peppers (Alvarez-Parrilla et al., 2011; Hervert-Hernández et al., 2011). Both achiote ABTS values were lower than those reported for annatto (Bixa orellana L.) seeds (Cardarelli et al., 2008), but similar to that reported for "colorífico", a Brazilian annattocorn flour paste similar to achiote (Barros Mariutti et al., 2008).

Table 3. Antioxidant activity of Mexican condiments ${ }^{\&}$.

\begin{tabular}{|c|c|c|c|c|c|c|c|c|c|c|}
\hline \multirow{2}{*}{ Sample } & \multirow{2}{*}{$\mathrm{DM}$} & \multicolumn{3}{|c|}{ FRAP } & \multicolumn{3}{|c|}{$\mathrm{DPPH}$} & \multicolumn{3}{|c|}{ ABTS } \\
\hline & & $\mathrm{ME}$ & $\mathrm{AE}$ & Total & $\mathrm{ME}$ & $\mathrm{AE}$ & Total & $\mathrm{ME}$ & $\mathrm{AE}$ & Total \\
\hline MM & 18.2 & $96.9 \pm 0.47^{\mathrm{e}}$ & $0.70 \pm 0.02^{c}$ & 97.6 & $11.6 \pm 0.66^{c}$ & $0.12 \pm 0.01^{\mathrm{c}}$ & 11.7 & $134.4 \pm 5.8^{\mathrm{d}}$ & $2.9 \pm 0.38^{\mathrm{d}}$ & 137.3 \\
\hline GM & 27.4 & $25.0 \pm 0.02^{\mathrm{f}}$ & $1.8 \pm 0.08^{c}$ & 26.8 & $1.78 \pm 0.11^{\mathrm{e}}$ & $0.63 \pm 0.06^{c}$ & 2.4 & $41.0 \pm 2.5^{\mathrm{e}}$ & $1.0 \pm 0.07^{\mathrm{d}}$ & 42.0 \\
\hline LT & 39.4 & $726.0 \pm 1.3^{\mathrm{a}}$ & $7.6 \pm 0.09^{\mathrm{b}}$ & 733.6 & $10.2 \pm 0.4^{\mathrm{c}}$ & $0.92 \pm 0.1^{c}$ & 11.1 & $292.0 \pm 18.3^{c}$ & $21.3 \pm 3.5^{c}$ & 313.3 \\
\hline RB & 39.3 & $211.6 \pm 7.4^{\mathrm{d}}$ & $6.5 \pm 0.4^{\mathrm{b}}$ & 218.1 & $8.1 \pm 0.2^{\mathrm{d}}$ & $0.52 \pm 0.07^{c}$ & 8.6 & $246.3 \pm 7.4^{c}$ & $19.0 \pm 0.44^{c}$ & 265.3 \\
\hline PP & 84.9 & $378.5 \pm 3.3^{\mathrm{b}}$ & $215.1 \pm 2.2^{\mathrm{a}}$ & 593.6 & $71.7 \pm 1.0^{\mathrm{a}}$ & $55.4 \pm 1.7^{\mathrm{b}}$ & 127.1 & $2129.9 \pm 106.7^{b}$ & $709.8 \pm 26.9^{\mathrm{a}}$ & 2839.7 \\
\hline
\end{tabular}

${ }^{v}$ Pasilla pepper (PP) samples; Dry matter (DM, \%), 80\% aqueous methanol extract (ME), 80\% aqueous acetone extract (AE), mean ME+AE (Total).vPasilla pepper (PP) samples; Dry matter (DM, \%), 80\% aqueous methanol extract (ME), 80\% aqueous acetone extract (AE), mean ME+AE (Total). 
The average values obtained in both radical scavenging assays (DPPH and ABTS) show that mole and achiote samples had 94\% and $67 \%$ less antioxidant activity than that of PP [standard error (EE) $\leq 27.4, p \leq 0.001]$, even when considering moisture and fat as covariates [standard error $(\mathrm{EE}) \leq 24.1, \mathrm{p} \leq 0.001$ ]. These results are in agreement with the lower content of phenolic compounds and flavonoids in mole and achiote samples, which may arise from low extraction capacity or losses due to the manufacturing procedures (intense heating for long periods) used to prepare these condiments (Alvarez-Parrilla et al., 2011; OrnelasPaz et al., 2010), despite the fact that many ingredients rich in phytochemicals are used to prepare them. When the results of the three assays for antioxidant activity are compared with each other, it is possible to observe that both radical scavenging methods show similar behavior.

\subsection{Oxidative stability}

Considering that PP, mole, and achiote pastes are commonly used in the Mexican cuisine to marinate pork, fish, chicken, turkey, and beef meat, their ability to inhibit lipid oxidation was evaluated by the thiobarbituric acid reactive substrates (TBARS) assay, using chopped pork meat as model. Pork meat was used as model system due to its high polyunsaturated fatty acid content, which made it more prone to oxidation (Juntachote et al., 2006). Raw ground pork meat had low TBARS content (approximately $0.1 \mathrm{mg}$ MDA Eq. $/ \mathrm{kg}$ meat), and its value increased to $0.3-0.4 \mathrm{mg}$ MDA Eq./kg meat after cooking for $45 \mathrm{~min}$ at $90^{\circ} \mathrm{C}$, showing that cooking promotes pork meat oxidation. Similar results were observed for pork (Alvarez-Parrilla et al., 2012) and chicken (Castro et al., 2011) meats. Lower values (0.17-0.29 mg MDA Eq./ kg) have been reported for raw pork sausages (Wenjiao et al., 2014), confirming the effect of cooking on the increase of TBARS in meat. Figure la shows the TBARS values for all cooked samples stored at $4^{\circ} \mathrm{C}$ for a 16-day period. As expected, all samples showed an increase in their TBARS values during storage (up to $8.6 \mathrm{mg}$ MDA Eq./kg meat for the control sample). Control sample (chopped pork meat mixed with water) showed the largest TBARS increase during the entire storage period. BHA-treated remained practically unchanged during storage (from 0.3 to $0.8 \mathrm{mg} \mathrm{MDA} \mathrm{Eq./kg} \mathrm{meat).} \mathrm{This} \mathrm{result} \mathrm{was}$ expected because BHA is a synthetic antioxidant commonly used as lipid oxidation protector in the food industry, and it is in agreement with previous studies that reported a high inhibition of lipid oxidation in cooked pork meat treated with BHA (Alvarez-Parrilla et al., 2012; Wijeratne et al., 2006). All other condiment treated samples showed intermediate inhibition values between control and BHA-treated samples.

The protective effect of Mexican condiments, expressed as inhibition of TBARS formation, at the end of the storage period (16 days) is depicted in Figure 1b. BHA showed a 90\% lipid oxidation inhibition, confirming the high protective effect of this synthetic antioxidant. Both Mole pastes showed the highest protective effect (45-52\% TBARS inhibition), followed by PP (29\%) and finally by both achiote pastes (almost $19 \%)$. These results were unexpected since mole showed the lowest phytochemical content and antioxidant activity, and consequently a lower TBARS inhibition was expected. Juneja et al. (2006) reported that cooked chicken marinated with a mixture of mole and grapefruit extract showed good protection against lipid oxidation and microorganism contamination. Even though low phytochemical content was determined for both mole extracts, its relatively high protective effect can be explained considering the complexity of its formulation. Mole paste contains ingredients with high protective effect against lipid oxidation such as clove (Kong et al., 2010), chocolate (Hassan \& Fan, 2005), and anise (Kong et al., 2010) among others; therefore, it is highly probable that mole extracts contain non-phenolic phytochemicals such as carotenoids and other mildly lipophilic compounds that may have a better lipidprotecting activity (Ornelas-Paz et al., 2013; Matsufuji et al.,
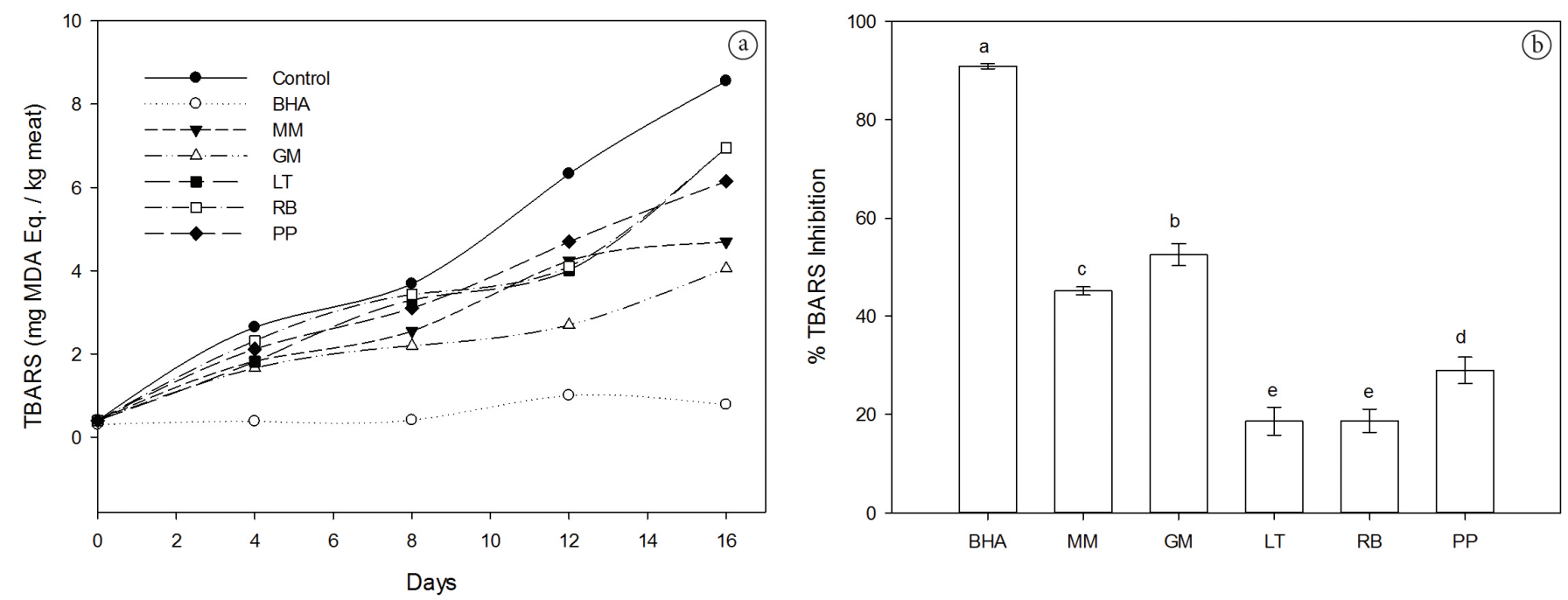

Figure 1. Oxidative stability of chopped pork meat (TBAR assay) (a) Progress of lipid oxidation in cooked pork meat during 16 days of storage at $4^{\circ} \mathrm{C}$ treated with $100 \mathrm{ppm} \mathrm{BHA}$ or condiment extracts (100 ppm GAE), (b) \% Inhibition of TBARS compared to that of the control at day 16 . Mean \pm SD $(n=4)$; Different superscript letters between bars means statistical differences $(\mathrm{p}<0.05) .{ }^{\star}$ Moles $(\mathrm{GM}, \mathrm{MM})$, achiotes $(\mathrm{LT}, \mathrm{RB})$, and Pasilla pepper (PP) samples. 
Table 4. Pearson product-moment correlation coefficients (r) for proximal \& phenolic compounds and antioxidant activity ${ }^{\&}$.

\begin{tabular}{|c|c|c|c|c|c|c|c|c|c|c|c|c|}
\hline & Moisture & Fat & Protein & Ash & CHOs & $\mathrm{FP}$ & $\mathrm{TF}$ & PA & FRAP & $\mathrm{DPPH}$ & ABTS & TBAR \\
\hline $\mathrm{TP}$ & $-0.934^{+}$ & -0.097 & $0.994^{+}$ & -0.360 & $0.923^{+}$ & 1 & & & & & & \\
\hline $\mathrm{TF}$ & $-0.980^{+}$ & -0.243 & $0.990^{+}$ & -0.197 & $0.977^{+}$ & $0.983^{+}$ & 1 & & & & & \\
\hline $\mathrm{PA}$ & $-0.738^{\star}$ & $-0.626^{*}$ & 0.559 & 0.566 & $0.760^{*}$ & 0.518 & 0.637 & 1 & & & & \\
\hline $\mathrm{DPPH}$ & $-0.936^{+}$ & -0.112 & $0.994^{+}$ & -0.352 & $0.927^{+}$ & $1.000^{+}$ & $0.985^{+}$ & 0.518 & 0.495 & 1 & & \\
\hline ABTS & $-0.956^{+}$ & -0.143 & $0.997^{+}$ & -0.299 & $0.948^{+}$ & $0.997^{+}$ & $0.993^{+}$ & 0.566 & 0.528 & $0.997^{+}$ & 1 & \\
\hline
\end{tabular}

${ }^{8}$ Total carbohydrates (CHOs), Total phenols (TP), flavonoids (TF), proanthocyanidins (PA); ion reducing (FRAP), and radical scavenging (DPPH, ABTS) antioxidant assays. ${ }^{*}$ Statistically significant at $\mathrm{p} \leq 0.01(+)$ and $\mathrm{p} \leq 0.05\left({ }^{*}\right)$

2007). A synergic effect of the extract's components may be responsible for the high TBARS inhibition activity found in this study. These results suggest the necessity to carry out further studies in which both polar (phenolic) and no polar (carotenoids) compounds are extracted from these matrixes in order to better explain the protective effect of these spices and condiments.

PP showed similar TBARS inhibition values to those reported for fresh and processed hot peppers in cooked pork or sausages (Martínez et al., 2006; Olorunsanya et al., 2009; Alvarez-Parrilla et al., 2012; Sánchez-Escalante et al., 2003). Achiote extracts showed the lowest protective effect against lipid oxidation ( 19\% inhibition). Castro et al. (2011) observed a 36\% TBARS inhibition in chicken patties treated with "colorifico" (Brazilian annatto-corn flour paste) and stored at $-18^{\circ} \mathrm{C}$; this higher inhibition of lipid oxidation compared to that of our results may be explained in terms of type of meat and storage temperature. Sancho et al. (2011) observed a 30\% lipid oxidation reduction in annatto and coriander treated fish meatballs stored at $-18^{\circ} \mathrm{C}$. Mercadante et al. (2010) reported that norbixin (one of the main carotenoids present in annatto seeds) showed the highest TBARS inhibition among different carotenoids used as food dyes. They suggested that this protective effect was due to accumulation of norbixin in the emulsion interface, thus preventing lipid oxidation. Considering this high protective effect of bixin and norbixin against lipid oxidation, the relatively low protective effect observed in the present study could be explained because the extraction procedure used in this research was optimized to extract phenolic compounds. Additionally, contents of these carotenoids in the commercial achiote pastes may be already importantly reduced, in comparison with those of annatto seeds, due to processing operations.

\subsection{Pearson product-moment correlation (PPMC)}

In order to elucidate which matrix or extract components show the strongest influence on the antioxidant activity and TBARS inhibition capacities of the assayed condiments, a PPMC analysis was performed. As shown in Table 4, high ( $r>0.94$, $\mathrm{p}<0.01)$ to moderate significant $(r>0.59, \mathrm{p}<0.05)$ correlations were found between moisture (inverse), protein, and carbohydrates (direct) with total phenols, flavonoids, DPPH, ABTS, proanthocyanidins, and FRAP, but not with TBARS. In addition, total phenols and flavonoids strongly correlated
( $\mathrm{r} \geq 0.985, \mathrm{p}<0.01)$ with DPPH and ABTS but proanthocyanidins $\operatorname{did} \operatorname{not}(\mathrm{r} \leq 0.57)$.

Similar correlations have been reported between total phenols and different methods to evaluate antioxidant activity with hot peppers (Alvarez-Parrilla et al., 2011; HervertHernández et al, 2010; Serrano et al., 2010) and vegetables and spices (Cho et al., 2007). On the other hand, proanthocyanidin content did not correlate with radical scavenging (DPPH, ABTS) capacity $(r \leq 0.57)$, phenols $(r=0.52)$, and flavonoid content $(\mathrm{r}=0.64)$ but, together with FRAP, they were inversely correlated with TBARS inhibition capacity $(r \geq 0.719, p<0.05)$. These results, together with those reported in Table 2, which show a low proanthocyanidin content in all extracts (except PP), suggest that these compounds are not major antioxidants in mole and achiote pastes. Lastly, the lack of correlation was also found between TBAR and TP, TF, DPPH, or ABTS may be explained considering that other components such as carotenoids may be responsible for the observed protective effect of $\mathrm{PP}$, mole, and achiote pastes.

\section{Conclusions}

Our results indicate that PP is a good source of phenolic compounds, flavonoids, and proanthocyanidins, with high antioxidant activity. Mole and achiote pastes showed lower phytochemical content and antioxidant activity probably due to degradation of phytochemicals during processing. However, low phytochemical content does not necessarily mean a low inhibitory capacity against lipid oxidation in chopped pork meat. Based on the above results, it can be said that the antioxidant activity of these three condiments (mole, achiote and PP) could be mainly attributed to their flavonoid and phenolic contents, while TBARS inhibition capacity depended not only on these phenolic compounds, but also on other more lipophilic compounds. Considering the widespread use of these condiments in the Mexican diet, the present study supports their use to prevent meat lipid oxidation.

\section{Acknowledgments}

The financial support provided by the Consejo Nacional de Ciencia y Tecnología, CONACYT, Mexico (CB-2011-01167932) is acknowledged. G. M.-M. wish to thank CONACYT for the master scholarship granted. 


\section{References}

Alasalvar, C., \& Shahidi, F. (2013). Dried fruits: phytochemicals and health effects. Ames: Wiley-Blackwell. http://dx.doi. org/10.1002/9781118464663

Alvarez-Parrilla, E., Rosa, L. A. de la, Amarowicz, R., \& Shahidi, F. (2011). Antioxidant Activity of Fresh and Processed Jalapeño and Serrano Peppers. Journal of Agricultural and Food Chemistry, 59(1), 163-173. PMid:21126003. http://dx.doi.org/10.1021/jf103434u

Alvarez-Parrilla, E., Rosa, L. A. de la, Amarowicz, R., \& Shahidi, F. (2012). Protective effect of fresh and processed Jalapeño and Serrano peppers against food lipid and human LDL cholesterol oxidation. Food Chemistry, 133(3), 827-834. http://dx.doi.org/10.1016/j. foodchem.2012.01.100

Alvarez-Parrilla, E., Rosa, L. A. de la, Martínez, N. R., \& GonzálezAguilar, G. A. (2007). Total phenols and antioxidant activity of commercial and wild mushrooms from Chihuahua, Mexico. Ciencia y Tecnología Alimentaria, 5(5), 329-334. http://dx.doi. org/10.1080/11358120709487708

Association of Official Analytical Chemistry - AOAC. (2000). Official methods of analysis (17th ed.). Maryland: AOAC.

Barros Mariutti, L. R., Barreto, G. P. M., Bragagnolo, N., \& Mercadante, A. Z. (2008). Free radical scavenging activity of ethanolic extracts from herbs and spices commercialized in Brazil. Brazilian Archives of Biology and Technology, 51(6), 1225-1232. http://dx.doi. org/10.1590/S1516-89132008000600018

Barros, C. (2005). Los moles: aportaciones prehispánicas. In $6{ }^{\circ}$ Congreso sobre Patrimonio Gastronómico y Turismo Cultural, Puebla, México. Cuaderno 12.

Bener, M., Özyürek, M., Güclü, K., \& Apak, R. (2010). Polyphenolic contents of natural dyes produced from industrial plants assayed by HPLC and novel spectrophotometric methods. Industrial Crops and Products, 32(3), 499-506. http://dx.doi.org/10.1016/j. indcrop.2010.06.020

Brand-Williams, W., Cuvelier, M. E., \& Berset, C. (1995). Use of a free radical method to evaluate antioxidant activity. $L W T$ - Food Science and Technology, 28(1), 25-30. http://dx.doi.org/10.1016/ S0023-6438(95)80008-5

Cardarelli, C. R., Benassi, M. T., \& Mercadante, A. Z. (2008). Characterization of different annatto extracts based on antioxidant and colour properties. LWT - Food Science and Technology, 41(9), 1689-1693. http://dx.doi.org/10.1016/j. lwt.2007.10.013

Castro, W. F., Mariutti, L. R. B., \& Bragagnolo, N. (2011). The effects of colorifico on lipid oxidation, colour and vitamin $\mathrm{E}$ in raw and grilled chicken patties during frozen storage. Food Chemistry, 124(1), 126131. http://dx.doi.org/10.1016/j.foodchem.2010.05.114

Cho, Y. S., Yeum, K. J., Chen, C. Y., Beretta, G., Tang, G., Krinsky, N. I., Yoon, S., Lee-Kim, Y. C., Blumberg, J. B., \& Russell, R. M. (2007). Phytonutrients affecting hydrophilic and lipophilic antioxidant activities in fruits, vegetables and legumes. Journal of the Science of Food and Agriculture, 87(6), 1096-1107. http://dx.doi.org/10.1002/ jsfa. 2817

Cortez García, R. M. (2011). Efecto del tratamiento térmico en las propiedades nutraceuticas del chile chilaca (Capsicum annuum L.). Mexico: Instituto Politécnico Nacional.

Díaz, A. M., Caldas, G. V., \& Blair, M. W. (2010). Concentrations of condensed tannins and anthocyanins in common bean seed coats. Food Research International, 43(2), 595-601. http://dx.doi. org/10.1016/j.foodres.2009.07.014
Efroymson, M. A. (1960). Multiple regression analysis. In A. Ralston \& H. S. Wilf (Eds.), Mathematical methods for digital computers. New York: John Wiley \& Sons.

Gutiérrez, J. E., Pérez, J. A., Poma, E. G., Yoshizawa, A. F., Arévalo, O. R., Peña, D. A., Benavides, N. E., Valdivia, E., Rodríguez Bayona, R., \& Landa, K. N. (2010). Actividad antioxidante del extracto hidroalcohólico de cuatro plantas medicinales y estimulación de la proliferación de fibroblastos. Revista de la Sociedad Química del Perú, 76(1), 73-79.

Hassan, O., \& Fan, L. S. (2005). The anti-oxidation potential of polyphenol extract from cocoa leaves on mechanically deboned chicken meat (MDCM). LWT - Food Science and Technology, 38(4), 315-321. http://dx.doi.org/10.1016/j.lwt.2004.06.013

Hervert-Hernández, D., García, O. P., Rosado, J. L., \& Goñi, I. (2011). The contribution of fruits and vegetables to dietary intake of polyphenols and antioxidant capacity in a Mexican rural diet: Importance of fruit and vegetable variety. Food Research International, 44(5), 1182-1189. http://dx.doi.org/10.1016/j.foodres.2010.09.021

Hervert-Hernández, D., Sáyago-Ayerdi, S. G., \& Goñi, I. (2010). Bioactive compounds of four hot pepper varieties (Capsicum annuum L.), antioxidant capacity, and intestinal bioaccessibility. Journal of Agricultural and Food Chemistry, 58(6), 3399-3406. PMid:20192220. http://dx.doi.org/10.1021/jf904220w

Juneja, V. K., Fan, X., Peña-Ramos, A., Diaz-Cinco, M., \& PachecoAguilar, R. (2006). The effect of grapefruit extract and temperature abuse on growth of Clostridium perfringens from spore inocula in marinated, sous-vide chicken products. Innovative Food Science and Emerging Technologies, 7(1-2), 100-106. http://dx.doi.org/10.1016/j. ifset.2005.09.004

Juntachote, T., Berghofer, E., Siebenhandl, S., \& Bauer, F. (2006). The antioxidative properties of Holy basil and Galangal in cooked ground pork. Meat Science, 72(3), 446-456. PMid:22061728. http:// dx.doi.org/10.1016/j.meatsci.2005.08.009

Kong, B., Zhang, H., \& Xiong, Y. L. (2010). Antioxidant activity of spice extracts in a liposome system and in cooked pork patties and the possible mode of action. Meat Science, 85(4), 772-778. PMid:20430533. http://dx.doi.org/10.1016/j.meatsci.2010.04.003

Loizzo, M. R., Pugliese, A., Bonesi, M., De Luca, D., O’Brien, N., Menichini, F., \& Tundis, R. (2013). Influence of drying and cooking process on the phytochemical content, antioxidant and hypoglycaemic properties of two bell Capsicum annum L. cultivars. Food and Chemical Toxicology, 53, 392-401. PMid:23266504. http:// dx.doi.org/10.1016/j.fct.2012.12.011

Madhujuth, T., \& Shahidi, F. (2007). antioxidative and antiproliferative properties of selected barley (Hordeum vulgarae L.) cultivars and their potential for inhibition of Low-Density Lipoprotein (LDL) cholesterol oxidation. Journal of Agricultural and Food Chemistry, 55(13), 5018-5024. PMid:17542605. http://dx.doi. org/10.1021/jf070072a

Marangoni, C., \& Moura, N. F. (2011). Antioxidant activity of essential oil from Coriandrum Sativum L. in Italian Salami. Ciência e Tecnologia de Alimentos, 31(1), 124-128. http://dx.doi.org/10.1590/ S0101-20612011000100017

Márquez, E., Pak, N., Araya, H., \& Rodríguez, J. L. (2006). Actividad antioxidante total de algunas hortalizas evaluadas mediante el ensayo FRAP. Ciencia y Tecnología Alimentaria, 16(1), 37-41.

Martínez, L., Cilla, I., Beltrán, J. A., \& Roncalés, P. (2006). Effect of Capsicum annuum (red sweet and cayenne) and piper nigrum (black and white) pepper powders on the shelf life of fresh pork sausages packaged in modified atmosphere. Journal of Food Science, 71(1), S48-S43. http://dx.doi.org/10.1111/j.1365-2621.2006.tb12405.x 
Matsufuji, H., Ishikawa, K., Nunomura, O., Chino, M., \& Takeda, M. (2007). Anti-oxidant content of different coloured sweet peppers, white, green, yellow, orange and red (Capsicum annuum L.). International Journal of Food Science and Technology, 42(12), 14821488. http://dx.doi.org/10.1111/j.1365-2621.2006.01368.x

Mercadante, A. Z., Capitani, C. D., Decker, E. A., \& Castro, I. A. (2010). Effect of natural pigments on the oxidative stability of sausages stored under refrigeration. Meat Science, 84(4), 718-726. PMid:20374848. http://dx.doi.org/10.1016/j.meatsci.2009.10.031

Mercado-Mercado, G., Rosa, L. A. de la, Wall-Medrano, A., López Díaz, J. A., \& Alvarez-Parrilla, E. (2013). Revisión compuestos polifenólicos y capacidad antioxidante de especias típicas consumidas en méxico. Nutrición Hospitalaria, 28(1), 36-46. PMid:23808428.

Oboh, G., Akomolafe, T. L., Adefegha, S. A., \& Adetuyi, A. (2011). Inhibition of cyclophosphamide-induced oxidative stress in rat brain by polar and non-polar extracts of Annatto (Bixa orellana) seeds. Experimental and Toxicologic Pathology, 63(3), 257-262. PMid:20137904. http://dx.doi.org/10.1016/j.etp.2010.01.003

Olorunsanya, A. O., Olorunsanya, E. O., Aliu, O. T., \& Kayode, R. M. O. (2009). Effects of different species of pepper (Capsicum) on oxidative stability of raw and cooked pork patties. Pakistan Journal of Nutrition, 8(10), 1588-1591. http://dx.doi.org/10.3923/ pjn.2009.1588.1591

Ornelas-Paz, J. J., Cira-Chávez, L. A., Gardea-Béjar, A. A., GuevaraArauza, J. C., Sepúlveda, D. R., Reyes-Hernández, J. R., \& Ruiz-Cruz, S. (2013). Effect of heat treatment on the content of some bioactive compounds and free radical-scavenging activity in pungent and non-pungent peppers. Food Research International, 50(2), 519-525. http://dx.doi.org/10.1016/j.foodres.2011.01.006

Ornelas-Paz, J. J., Martinez-Burrola, J. M., Ruiz-Cruz, S., SantanaRodríguez, V., Ibarra-Junquera, V., Olivas, G. I., \& Pérez-Martínez, J. D. (2010). Effect of cooking on the capsaicinoids and phenolics contents of Mexican peppers. Food Chemistry, 119(4), 1619-1625. http://dx.doi.org/10.1016/j.foodchem.2009.09.054

Otunola, G. A., Oloyede, O. B., Oladiji, A. T., \& Afolayan, A. J. (2010). Comparative analysis of the chemical composition of three spices - Allium sativum L. Zingiber officinale Rosc. and Capsicum frutescens L. commonly consumed in Nigeria. African Journal of Biotechnology, 9(41), 6927-6931.

Rosa, L. A. de la, Alvarez-Parrilla, E., \& Shahidi, F. (2011). Phenolic Compounds and Antioxidant Activity of Kernels and Shells of Mexican Pecan (Carya illinoinensis). Journal of Agricultural and Food Chemistry, 59(1), 152-162. PMid:21138247. http://dx.doi. org/10.1021/jf1034306

Rufián-Henares, J. A., Guerra-Hernández, E., \& García, V. B. (2013). Effect of red sweet pepper dehydration conditions on Maillard reaction, ascorbic acid and antioxidant activity. Journal of Food Engineering, 118(1), 150-156. http://dx.doi.org/10.1016/j. jfoodeng.2013.03.034

Sánchez-Escalante, A., Torrescano, G., Djenane, D., Beltrán, J. A., \& Roncalés, P. (2003). Stabilisation of colour and odour of beef patties by using lycopene-rich tomato and peppers as a source of antioxidants. Journal of the Science of Food and Agriculture, 83(3), 187-194. http://dx.doi.org/10.1002/jsfa.1298

Sancho, R. A. S., Aliaga de Lima, F., Guerra Costa, G., Barros Mariutti, L. R., \& Bragagnolo, N. (2011). Effect of annatto seed and coriander leaves as natural antioxidants in fish meatballs during frozen storage. Journal of Food Science, 76(6), C838-C845. PMid:22417481. http:// dx.doi.org/10.1111/j.1750-3841.2011.02224.x

Serrano, M., Zapata, P. J., Castillo, S., Guillén, F., Martínez-Romero, D., \& Valero, D. (2010). Antioxidant and nutritive constituents during sweet pepper development and ripening are enhanced by nitrophenolate treatments. Food Chemistry, 118(3), 497-503. http:// dx.doi.org/10.1016/j.foodchem.2009.05.006

Shahidi, F., \& Zhong, Y. (2010). Lipid oxidation and improving the oxidative stability. Chemical Society Reviews, 39, 4067-4079. PMid:20617249. http://dx.doi.org/10.1039/b922183m

Tocchini, L., \& Mercadante, A. Z. (2001). Extração e determinação, por clae, de bixina e norbixina em coloríficos. Ciência e Tecnologia de Alimentos, 21(3), 310-313. http://dx.doi.org/10.1590/S010120612001000300010

United Nations Organization for Education, Science and Culture - UNESCO. (2010). Traditional Mexican cuisine: ancestral, ongoing community culture, the Michoacán paradigm. Paris: UNESCO. Retrieved from http://www.unesco.org/culture/ich/ index.php? $1 \mathrm{~g}=\mathrm{en} \& \mathrm{pg}=00011 \& \mathrm{RL}=00400$

Vega-Gálvez, A., Di Scala, K., Rodríguez, K., Lemus-Mondaca, R., Miranda, M., López, J., \& Perez-Won, M. (2009). Effect of air-drying temperature on physico-chemical properties, antioxidant capacity, colour and total phenolic content of red pepper (Capsicum annuum, L. var. Hungarian). Food Chemistry, 117(4), 647-653. http://dx.doi. org/10.1016/j.foodchem.2009.04.066

Wenjiao, F., Yongkui, Z., Yunchuan, C., Junxiu, C., \& Yuwen, Y. (2014). TBARS predictive models of pork sausages stored at different temperatures. Meat Science, 96(1), 1-4. PMid:23896130. http:// dx.doi.org/10.1016/j.meatsci.2013.06.025

Wijeratne, S. S. K., Amarowicz, R., \& Shahidi, F. (2006). Antioxidant activity of almonds and their by-products in food model systems. Journal of the American Oil Chemists' Society, 83(3), 223-230. http:// dx.doi.org/10.1007/s11746-006-1197-8 